\title{
AMICUS CURIAE BRIEFS IN THE WTO DSM: GOOD OR BAD NEWS FOR NON-STATE ACTOR INVOLVEMENT?
}

Forthcoming in World Trade Review

\section{Theresa Squatrito}

\begin{abstract}
Since 1998, non-state actors have had access to submit an "amicus curiae" brief to the WTO DSM. Like other forms of non-state actor involvement in the WTO, amicus curiae access has been controversial. Despite this controversy, non-state actors have made use of this access and submitted amicus curiae briefs. This article asks: what has come of these briefs once they are submitted and what explains how amicus are treated by the DSM? This article empirically maps amici in all disputes from 1998 (after amicus access was first recognized) through 2014, arguing that amicus access is conditioned by a combination of political and legal constraints faced by the WTO panels and AB. In particular, whether the content of an amicus is considered hinges on it having the endorsement of a disputing party and whether its consideration interferes with the WTO DSM's reputation for coherence. In all, these findings have implications for the debate over whether amicus curiae access is good new or bad news for the WTO and non-state actor involvement.
\end{abstract}

\section{Introduction}

The involvement of non-state actors in the World Trade Organization's (WTO) has been a controversial issue. Policy-makers and scholars have since the late 1990s disputed the merits and shortcomings of granting access to the WTO for non-state actors (Scholte, O'Brien, and Williams 1999, Charnovitz 2000, Van den Bossche 2008). Proponents of access herald it as a means of enhancing the legitimacy and effectiveness of decision-making. On the other hand, opponents of non-state actors' involvement contend that it enables the undue influence of 
special interests and undermines efficient decision-making. The issue of non-state actors' involvement in the WTO extends to all corners of the WTO, including the WTO's dispute settlement mechanism (DSM). Since 1998, non-state actors have been formally allowed access to submit an "amicus curiae" brief to the WTO dispute settlement mechanism. As with other forms of non-state actor access to the WTO, access to the DSM has been contentious. Against this backdrop, amicus access has been available to non-state actors for over fifteen years, and non-state actors have made use of this access and submitted amicus curiae briefs. What comes of these briefs once they are submitted: are they all accepted and then their content taken into consideration by the WTO DSM in deliberation and decision-making, or is this access conditional? What explains how amicus are treated by the DSM? This article seeks to answer these questions.

An empirical examination of amicus curiae submissions to the WTO DSM and how the WTO DSM treats the amicus submissions sheds light on the merits and shortcomings of non-state actors' access to the WTO DSM. This article's contribution to the ongoing debates on the involvement of non-state actors in the WTO is twofold. First, the article provides an empirical contribution by mapping non-state actors' participation in the WTO DSM as amici in all disputes from 1998 (after amicus access was first recognized) through 2014. While there has been recent research that has explored participation in the WTO Ministerial Conferences (Hanegraaff, Beyers, and Braun 2011, Hanegraaff et al. 2015), similar systematic empirical research on amicus curiae submissions has not been carried out. This article fills this gap, mapping all amicus submission from 1998 to 2014. Second, the article makes a theoretical contribution, arguing that amicus curiae access is conditional. While most of the debate regarding amici largely rest on the assumption that once an amicus is filed its substantive content will be considered and factored into deliberation and decision-making, this article 
shows that additional factors condition access to the WTO DSM. Showing that amicus curiae access is conditional has implications for understanding their consequences.

This article reveals that amicus curiae submissions, contrary to some expectations, have not flooded the WTO DSM. In fact, amicus curiae submissions have been received in only a minority of disputes. Additionally, this article shows access as an amicus is conditional - not all amicus briefs that are received are considered in the deliberation and decisionmaking of the WTO panels and Appellate Body (AB). I argue that whether an amicus is considered is shaped by the DSM's political and legal constraints. Specifically, two factors condition whether their content is taken into consideration by the panels and AB. First, the DSM only considers amicus submissions that are endorsed by a disputing party. Second, the DSM accepts and considers amicus only if they can secure the WTO DSM's reputation for coherence. As a result of these two factors, amicus curiae access is conditional and therefore not all amicus curiae submissions translate into meaningful participation in the WTO DSM.

The article is organized in four parts. The first part provides an empirical mapping of amicus curiae submissions to the WTO DSM. The second part develops a theoretical account to explain whether the panels and $\mathrm{AB}$ consider and deliberate on the content of an amicus curiae submission. This account draws from previous literature that illustrates how international adjudication is constrained by law and politics. The third part comprises the empirical analysis and explores how well the theoretical account matches how the WTO panels and $\mathrm{AB}$ have treated amicus submissions. The argument is tested using multivariate statistical analysis and qualitative content analysis. The fourth part offers a discussion of the findings and its implications.

\section{Amicus Submissions to the WTO Dispute Settlement Mechanism}


A submission by an amicus curiae, or "friend of the court," presents an individual or group with the opportunity to participate in a dispute by way of contributing factual information and legal arguments to the WTO panels and AB. Amici curiae can serve at least three functions: (1) provide legal analysis, (2) provide factual evidence and analysis, (3) provide information on how the dispute relates to a broader political and social context (Van den Bossche 2008, 739).

The WTO's Dispute Settlement Understanding (DSU) does not explicitly provide the dispute panels or the Appellate Body with the authority to receive and use amicus submissions. However, a panel addressed whether or not it had the authority to accept and consider an amicus curiae submission in 1998 after receiving two briefs from environmental groups in connection with the US-Shrimp dispute. ${ }^{1}$ The panel found it did not have the authority to consider such briefs because they were unsolicited. The panel's understanding was that while Article 13 of the DSU permitted panels to seek information and technical advice, such information had to be requested by the panel. Thus, "accepting non-requested information from non-governmental sources would be, in our opinion, incompatible with the provisions of the DSU..."2 However, the panel did allow for amici to be attached to parties' submissions for consideration, which the US had done with the two briefs. Later when the dispute was appealed, the $\mathrm{AB}$ disagreed with the panel's findings, opting for a broader interpretation of Article 13. It found that "[a] panel has the discretionary authority either to accept and consider or to reject information and advice submitted to it, whether requested by the panel or not. The fact that a panel may motu proprio have initiated the request for information does not, by itself, bind the panel to accept and consider the information which is

\footnotetext{
${ }^{1}$ United States - Import Prohibition of Certain Shrimp and Shrimp Products, Report of the Panel. WTO/DS58/R, May 15, 1998.

2 Ibid., para. 7.8 .
} 
actually submitted." ${ }^{3}$ In addition, the $\mathrm{AB}$ affirmed that the panel was entitled to consider the amicus which the US had appended to its own submissions. This decision, however, left unresolved whether the AB could accept and consider an amicus submission on its own (Stern, 2005: 1433-1435).

The AB later decided that it could also accept an amicus brief and take it into account. The $\mathrm{AB}$ found that Article 17.9 of the DSU accorded the $\mathrm{AB}$ with the authority to draw up its own working procedures, and thus the $\mathrm{AB}$ has "the legal authority to decide whether or not to accept and consider any information that [it] believe[s] is pertinent and useful in an appeal."4 While asserting its authority to accept and consider an amicus submission, the $\mathrm{AB}$ did not establish any rules governing when it could make use of this authority. The following year, the $\mathrm{AB}$ in its review of the Asbestos dispute, adopted a working procedure for the admission of amicus curiae briefs. ${ }^{5}$ While the procedure was only to apply to this dispute and all submissions were in the end denied acceptance, it gave way to further integration of amicus submissions in the DSM while also leaving unclear when amici could be accepted and considered.

These developments regarding amicus submissions gave rise to a wave of public discourse around the AB's ruling on amicus curiae (Umbricht 2001, 775-76). States reacted strongly to the decisions, culminating in a special session of the WTO General Council held on November 22, 2000 to discuss the amicus procedure adopted by the AB. During this session, states overwhelmingly expressed disapproval with the acceptance of amici (Umbricht 2001, 776). In later negotiations to reform the DSU, amicus submissions were a source of contention between states because they had divergent preferences on whether amici should be

\footnotetext{
${ }^{3}$ United States - Import Prohibition of Certain Shrimp and Shrimp Products, Report of the Appellate Body. WTO/DS58/AB/R, May 15, 1998, para. 108.

${ }^{4}$ United States - Imposition of Countervailing Duties on Certain Hot-Rolled Lead and Bismuth Carbon Steel Products Originating in the United Kingdom, Report of the Appellate Body. WTO/DS138/AB/R, May 10, 2000, para. 39.

${ }_{5}^{5}$ European Communities - Measures Affecting Asbestos and Products Containing Asbestos, Report of the Panel. WTO/DS135/R, September 18, 2000.
} 
permitted (Squatrito 2012). State negotiations to reform the DSU never led to a formal change to the DSU. Nevertheless, amicus submissions remain controversial, and some states continue to openly oppose them.

The debate surrounding amicus curiae submissions has been multifaceted and the arguments varied. Two main threads however can be identified: one concerns the consequences of amici for decision-making effectiveness and the other concerns the consequences for the WTO DSM's legitimacy. Proponents of amicus curiae access have argued that amicus curiae access can improve decision-making effectiveness by improving the quality and diversity of information. Non-state actors have information and resources that states lack, and thus their inclusion can ensure decision-making is based on more and better information (Esty 1998). Proponents also argue that amicus curiae submissions can help to alleviate aspects of the WTO DSM's legitimacy deficit that arises from its lack of transparency and openness to non-state actors. Amicus curiae access enables stakeholders other than states to be heard in the WTO DSM, increasing public participation and representation of the varying interests that are affected by decisions made through the WTO DSM (Charnovitz 2000, Esty 1998).

Opponents of access similarly point to concerns of effectiveness of decision-making and legitimacy. They argue that amicus submissions diminish the effectiveness of decisionmaking by increasing the number of participants which can make coming to decisions more cumbersome. Some contend that WTO dispute settlement does, in the absence of amicus curiae access, include considerable participation for non-state actors (Dunoff 1998). Others argue that legitimacy is not improved by non-state actor involvement because many of these actors may be lacking in their own democratic credentials (Trachtman and Moremen 2003) or because it does not address the fundamental issue of transparency (Slotboom 2006). Similar arguments suggest that amici would weaken the legitimacy of the WTO DSM by leading to an 
overrepresentation of certain interests and their undue influence on decision-making (Shaffer 2001). This argument is largely based on the assumption that amici will predominately represent the interests of the global North, such as environmentalists and labor, to the detriment of the developing world. Accordingly, opponents of amicus submissions argue that such non-state actor involvement hinders fairness in the WTO DSM, and rather than promote its legitimacy, would diminish it as a consequence of introducing systematic bias in the DSM.

Both of these general arguments tend to assume that once submitted amicus briefs are factored into the deliberation and decision-making of the panels and $\mathrm{AB}$. However, whether this is the case is not clear. A variety of non-state actors, such as environmental NGOs, academics, trade unions, public health associations, and industry associations, have continued to file submissions to the dispute panels and the $\mathrm{AB}$, despite the controversy surrounding amicus curiae at the WTO. What has come of these amici?

To address this question, I draw upon an original dataset, covering disputes that have been adjudicated by the WTO panels and AB. The dataset comprises all WTO disputes in which a panel or $\mathrm{AB}$ report has been issued through the end of 2014. The data include information on whether an amicus was filed in each dispute before a panel or the $\mathrm{AB}$, as well as general dispute characteristics. When an amicus is filed, disputes are coded for the amicus characteristics, including name of the organization, whether the amicus is jointly filed by more than one organization, the territorial origin of the organization and the type of organization. $^{6}$ The categories for territorial origin and organization type are borrowed from Hanegraaff, Beyers, and Braun (2011). In addition, the dataset includes information on how the panel and the $\mathrm{AB}$ respond to each amicus brief (based on the report's description of how

\footnotetext{
${ }^{6}$ Coding on each amicus party is guided by information recorded in the panel and AB reports, the Yearbook of International Organizations, the ECOSOC database, and WTO Ministerial Conference NGO accreditation lists. Where information on organization type and territorial origin could not be discerned from these sources, I relied on self-representation of amici actors on their webpages. For a few actors, I used other sources.
} 
the panel or $\mathrm{AB}$ treated the amicus) as well as characteristics of the dispute. Here I briefly describe the general patterns identified by the data.

Figure 1 illustrates the annual proportion of panel and Appellate Body reports involving disputes where at least one amicus submission was received. While there is a slight upward trend over time in the portion of disputes in which amici were filed, there is considerable variation from year to year. Figure 1 also reveals that in most disputes the panels or $\mathrm{AB}$ do not receive an amicus submission. During most years, less than $50 \%$ of the panel and $\mathrm{AB}$ reports had at least one amicus submission filed. In this sense, amicus submissions are usually the exception, rather than the rule. Nevertheless, in some years, the proportion of disputes with submissions is noteworthy. In total, 21 of $144(15 \%)$ panel reports have involved disputes to which there were amici filed. Amici were submitted in seventeen out of 70 (or 24\%) of the disputes reviewed by the Appellate Body where reports were circulated through 2014. Of all disputes brought to the WTO DSM, only 30 had amicus submissions at either or both the panel and AB. Moreover, in all but seven of these 30 disputes either the US or the European Union was the respondents in the dispute. ${ }^{7}$

[FIGURE 1 about here]

In total, there have been 98 amicus submissions representing 148 actors. Some amicus actors have filed or joined an amicus in more than one dispute. For example, American Public Health Association and Greenpeace International have been repeat filers, submitting amicus curiae briefs in more than one dispute. Table 1 illustrates the distribution of amicus actors by territorial origin. Most amicus actors are from North America (the US or Canada) and Europe. In fact, roughly $68 \%$ of all amicus actors come from these two regions. Approximately $20 \%$

\footnotetext{
${ }^{7}$ See appendix for complete list of disputes in which amicus submissions were received.
} 
of all actors on whose behalf an amicus has been filed come from South America, Africa or Asia. The territorial origins of amicus actors are as some opponents of access expect: there is a disproportionate representation of the global North. However, one should bear in mind that the US or the EU were the respondents in most of the disputes in which amici were filed.

In addition to the territorial origin of amici actors, there is diversity in the types of organizations that have filed amici. Table 2 presents the distribution of amici actors by organization type. The data confirm there is diversity, and all types of organizations have filed amici. NGOs represent the largest proportion of amici actors, followed by business organizations and institutes. ${ }^{8}$ Also, there have been submissions by groups or individuals representing both economic and non-economic interests.

[Table 1 and Table 2 about here]

Given this distribution of volume and diversity in amicus curiae submissions, the question remains: does submission mean an amicus brief is considered by the WTO panels and $\mathrm{AB}$, or is access conditional? While the panels and $\mathrm{AB}$ read all of the amicus submissions they receive, ${ }^{9}$ they do not always address the content of all amicus submissions in their deliberation and analysis. In other words, not all amicus are actively considered. ${ }^{10}$ Table 3 summarizes how the WTO panels and AB have treated all submitted amicus briefs, as explicitly described by their reports. In most instances the panels or $\mathrm{AB}$ do not 'take into consideration" the content of the submissions in their decisions. In total, $81.5 \%$ of amicus submissions were not considered by the panel or $\mathrm{AB}$. While the reasons for not being

\footnotetext{
${ }^{8}$ Institutes are institutions "without members (companies, individuals, or direct sponsors) and encompass organizations such as think-tanks, local government and authorities, and universities" (Hanegraaff, Beyers, and Braun 2011, 462, note 11).

${ }^{9}$ Interview A, WTO Legal Affairs Division Staff Member. Geneva, October 16, 2014.

${ }^{10}$ I use the term "consider" because it is commonly used by the panels and AB to indicate the content is addressed.
} 
considered vary, it is most common for the panels or $\mathrm{AB}$ to state that the information provided by the amici is "not necessary" to consider. ${ }^{11}$ Amici are generally ruled to be unnecessary to consider in one of two situations. First, many of the amici are not considered because, as described in the reports, they contain information that is not useful or pertinent to the questions before the panel or AB. Second, in other instances amicus submissions are not necessary to consider because they do not provide original information. Rather, they repeat the information presented in the state parties arguments.

[TABLE 3 about here]

Nonetheless, amicus are accepted and considered in some instances. As Table 3 illustrates, the content of $18.5 \%$ of amicus submissions are taken into consideration. Thus, it is not common for the content of an amicus brief to be openly considered by a panel or the AB. Figure 1 above depicts the yearly rate at which amicus submissions are taken into consideration. It illustrates that the rate of amicus consideration fluctuates from year to year. There appears to be an upward trend toward higher acceptance from 1999 until 2009, but then a decline. The time trend is influenced by 2009 , when there was only one amicus submitted that was subsequently taken into consideration. Sixteen amicus submissions have formally been accepted and considered by panels. It is especially rare for the AB to consider an amicus brief. In fact, the $\mathrm{AB}$ has only found one amicus to merit consideration. In all other instances, the $\mathrm{AB}$ has either rejected the briefs without explanation or found them not necessary to consider. How can we explain this pattern of response from the WTO DSM to amicus submissions?

\section{Explaining WTO DSM Acceptance of Amicus Submissions}

\footnotetext{
11 "Necessary" is the term commonly used by the panels or AB when describing their treatment of amicus briefs.
} 
The previous section illustrated that non-state actors do try to engage with the WTO DSM by submitting amicus submissions. Nevertheless, not all amici that are submitted are considered by the panels of AB. Rather, the WTO DSM's consideration of amicus submission varies, making access conditional. To explain this variation, this section builds on central insights from research on international adjudication, positing that a combination of political and legal factors condition whether amici submissions are accepted and considered by the WTO panels and $\mathrm{AB}$.

Previous research on international courts and tribunals suggests that international adjudicators operate within a complex environment of legal and political constraints (Steinberg 2004, Garrett, Kelemen, and Schulz 1998, Stone Sweet and Brunell 2013). The WTO DSM has been shown to similarly operate under both political and legal constraints (Steinberg 2004, McCall Smith 2003, Kelemen 2001). Consequently, adjudicators adopt strategic behaviors to accommodate these constraints. First, international adjudicators operate within political contexts which constrain their behavior. Adjudicators are politically constrained because they have incentives to ensure their judgments are complied with, to deter court curbing (or any political action that could undermine the authority of the court or tribunal), and to more broadly maintain the court or tribunal's institutional integrity and legitimacy (Garrett, Kelemen, and Schulz 1998, Carrubba, Gabel, and Hankla 2008, Elsig and Pollack 2014, Larsson and Naurin 2016). While international adjudicators are unlikely to overtly yield to political pressure (especially from states), they may nonetheless adopt strategies in their judicial decision-making that can help to insulate them from political pressure, such as using judicial economy (Busch and Pelc 2010). In other words, international adjudicators are concerned with their reputation and position vis-à-vis political audiences. 
Second, alongside political constraints international adjudicators confront legal constraints. Legal constraints include specific legal provisions that limit the discretion of adjudicators; that is, the law itself may constrain. Legal constraints can also arise from the broader concern of maintaining legal legitimacy. International courts draw legal legitimacy, in part, from the professional and moral authority of their judges or adjudicators. Specifically, judges have moral authority because they serve higher ideals and based on respect for their expertise (Alter 2008). Failures to judge according to law, or to violate ethics of the profession, such as fairness and impartiality, could weaken their claim to authority and compromise the integrity of the court or tribunal they serve. Thus, in addition to having incentives that are shaped by their political audiences, international adjudicators are constrained by the law and their position vis-à-vis legal audiences.

International adjudicators confront a combination of political and legal constraints. I posit that the combination of political and legal constraints that international adjudicators face can account for the variation in whether the panels and $\mathrm{AB}$ take into consideration an amicus submission. Specifically, the panels and $\mathrm{AB}$ are likely to restrict their acceptance and consideration of amici to those that accommodate the legal and political constraints faced by the WTO DSM. In the following, I discuss two conditions in particular that are likely to enable an amicus to accommodate these constraints.

First, to accommodate its political constraints the WTO DSM is more likely to accept and consider an amicus when it accords with the preferences of one or more disputing parties. As Ginsburg argues, "courts need the support of particular audiences. Sometimes this will be a particular state or a set of states powerful enough to insulate the court from attacks and pressure" (Ginsburg 2013, 494). Restricting the consideration of an amici to those that accord with the preferences of a disputing party enables the panel or $A B$ to shield itself politically by aligning itself with the preference of the state(s) that benefits from the amicus submission. In 
other words, when a disputing party validates the information provided by an amicus, it is less politically costly for the panel or $\mathrm{AB}$ to actively engage it in its adjudication.

States make their preferences known to adjudicators through a variety of means. They make their preferences known to adjudicators in their written and oral interventions as a direct litigating party or as a third party during legal proceedings. Adjudicators can also identify state preferences through official statements made in other venues. For example, the WTO's Appellate Body may infer state preferences from what states have stated in meetings of the WTO's General Council or highly visible public fora. Adjudicators might also be able to infer state preferences from domestic law and policy, assessing "aggregate state practice in order to arrive at some measure of the extent of regime consensus on a relevant policy issue; the degree of policy consensus is then treated as an important fact bearing on the case at hand" (Stone Sweet and Brunell 2013,63). They can look at what portion of states has laws or policies that would resemble that which the court would prefer to advance in its decisions. However, as amicus submissions have been especially controversial in the WTO, as discussed above, the panels and $\mathrm{AB}$ are likely to rely upon the expressed preference of a disputing party that an amicus be considered, as this provides the most certainty that a disputing party's preferences align with the amicus. For example, previous research found that the panels and AB only address arguments of amicus actors if their briefs were appended to a state's submissions (Dunoff 2006, 660). Appending a brief, however, is only one possible way in which a party to the dispute can express a preference that an amicus submission be considered. Consequently, we would expect that an amicus curiae brief is more likely to be considered by a panel or the $\mathrm{AB}$ if a disputing party expressly supports its consideration.

Second, the panels and $\mathrm{AB}$ are more likely to accept and consider an amicus when it does not interfere with the WTO DSM's reputation for coherence. Coherence is the treatment of "like cases as alike", or that rules 'be applied uniformly in every 'similar' or 'applicable' 
instance" (Franck 1995, 38). ${ }^{12}$ Coherence therefore depends on the consistent application of rules. Maintaining a court's reputation for coherence is an important way by which international adjudicators can boost the legal legitimacy of an international court or tribunal (Kelemen 2001, 625), especially in relation to its reputation with legal audiences. International adjudicators' consistent application of the law improves their reputation with legal audiences because it increases adherence to the law (Franck 1990). It also advances the view that the law is neutral or "fair" (Franck 1995, Dworkin 1986). Thus, to be viewed as authoritative interpreters of law, judges aim for coherence in their decision-making (McCall Smith 2003, 75).

If the acceptance and consideration of amicus briefs is conditioned by the panels' and $\mathrm{AB}$ 's interests to maintain a reputation for coherence, we would expect the panels and $\mathrm{AB}$ to treat amicus briefs similarly, in accordance to similar procedures. Consequently, we would observe a consistent and principled treatment of amici, and in accordance with the law and legal principles. For example, we should find that the territorial origin of the amicus actor does not determine whether it is considered. Also, to preserve a reputation for coherence, the DSM would most likely refrain from considering amici in their legal analysis, but not necessarily in their factual analysis. For this reason, we should find that amicus submissions that provide information on the facts of the dispute, not on law, to be more likely to be considered.

If the WTO DSM is constrained by both political and legal concerns, either of these conditions alone is unlikely to sufficiently account for how the panels and the AB handle amicus curiae briefs. Rather, the best explanatory leverage for whether an amicus submission is considered derives from the combination of the two factors. For this reason, we would

\footnotetext{
${ }^{12}$ Ronald Dworkin (1986) refers to coherence as "integrity."
} 
expect an amicus curiae brief to be accepted and considered only if: (1) it is expressly endorsed by a disputing party, and (2) it advances the WTO DSM's reputation for coherence.

The combination of political and legal constraints is greater for the Appellate Body than the panels, making it less likely that the $\mathrm{AB}$ will consider amici. The $\mathrm{AB}$ faces greater political constraints. As panels are the tribunal of first instance, states can always contest the findings of panels by appealing to the $\mathrm{AB}$. The $\mathrm{AB}$ decisions, however, can only be reversed by political override. Also, the appointment of $\mathrm{AB}$ members is political. As Steinberg explains, “...Appellate Body members are selected through a process in which powerful members may veto candidates whom they assess as likely to engage in inappropriate or undesired lawmaking; the Appellate Body acts in the shadow of threats to rewrite DSU rules that would weaken it and of possible defiance of its decisions by powerful members; and the Appellate Body receives-and has established means of obtaining-information on the preferences of powerful members, helping it to avoid political pitfalls. Hence, WTO legal discourse has been applied in a manner that pays attention to political signals, and the Appellate Body's interpretations generally rest within the interstices of WTO texts" (Steinberg 2004, 274). Also, the AB most likely treats amicus submissions in light of its past experience of backlash by states. Thus, the $\mathrm{AB}$ is in a more politically precarious position when it comes to amicus submissions than the panels.

Moreover, the $\mathrm{AB}$ has legal constraints that the panels do not, reducing the likelihood that it will accept and consider amicus submissions. The AB does not rule on factual arguments but only on rulings of law (Marceau and Hurley 2012, 30). Consequently, information provided by an amicus that would ordinarily assist in a factual determination is legally constrained from consideration by the $\mathrm{AB}$. Amicus actors do not necessarily know that the $\mathrm{AB}$ makes only legal determinations, and they might submit factual information regardless, causing their submission to fall outside the realm of what the $\mathrm{AB}$ can legal consider. Also, the 
AB's reputation with legal audiences could suffer from relying on non-legal authorities for legal arguments. As the political and legal constraints are greater for the $\mathrm{AB}$ than the panels, we would expect the $\mathrm{AB}$ to be less likely to accept and consider amicus submissions.

\section{Empirical Analysis}

In this section, I illustrate how the theoretical expectations stand up empirically using mixed-methods. The empirical analysis builds on the original dataset presented above, which includes all disputes adjudicated by the WTO panels and AB through the end of 2014. I test the theoretical expectations through multivariate statistical analysis first. A qualitative content analysis of the panel and $\mathrm{AB}$ reports, as well as interview material, then follows to complement the statistical analysis. A mixed methods approach is necessary because there is relatively small number of amicus submissions for large $\mathrm{N}$ analysis. The qualitative analysis fills gaps in the quantitative analysis, while also adding nuance and content to the analysis. Overall, the empirical analysis shows that state endorsement of an amicus as well as WTO DSM's interests to secure its reputation for coherence in adjudication condition whether amicus briefs are considered by the WTO dispute settlement system.

\section{Multivariate Analysis}

To test what determines whether an amicus submission is taken into consideration by the WTO DSM, I begin with a binomial logistic regression, with standard errors clustered by dispute because some disputes have been subject to more than one amicus submission. The unit of analysis is the amicus submission. The dependent variable considered is a binary measure of whether the panel or $\mathrm{AB}$ report states that it took into consideration, at least in part, the amicus submission. I test the effect of three key factors on the dependent variable. First, I test the effect of territorial origin and organization type of the actors who file the amicus 
submission. These are measured as dummy variables for each territorial origin and organization type. The theoretical expectation for legal coherence is that the territorial origin should not determine the likelihood an amicus is considered. Also, if legal coherence is a constraint, organization type should not affect consideration, with the exception of institutes. ${ }^{13}$ Factual information is the least likely to interfere with legal coherence and among organizations types, institutes are the most likely to provide factual information. Thus, amicus submissions from institutes, as opposed to all other types of organizations, are more likely to be considered.

\section{[TABLE 4 here]}

A cross-tabulation of the rate at which amicus are considered by their territorial origin and organization type seems to correspond to these expectations. Table 5 illustrates there are few strong tendencies for amicus consideration to be associated with amici of a particular territorial origin or organization type. The territorial origin of amicus actors appears to have little bearing on their acceptance. While amicus briefs from Asia, Oceania, and South America have not been considered, this is driven in part by the few amicus submitted from these regions. Also, organization types have similar rates of consideration, with the exception of business or industry associations. At the same time, of amicus actors for which the type is known, institutes have the highest rates of acceptance.

The multivariate analysis also tests the effect of expressed support, measured as whether a direct party to the dispute claims that the amicus should be considered by the panel or $\mathrm{AB}$ or that the panel or $\mathrm{AB}$ has the authority to consider amici. This variable is coded based on the panel and $\mathrm{AB}$ reports' description of the parties' position on the amicus. It does not capture whether the party incorporates the substantive content of the amicus into its own

\footnotetext{
${ }^{13}$ Most of the amicus actors coded as institutes are universities.
} 
submission, but rather it captures statements of general support for the amicus to be considered by panel or $\mathrm{AB}$.

Two controls are included in the analysis. First, previous literature suggests that the more third parties there are to a dispute the more politically salient or contentious the dispute is (Busch and Reinhardt 2006). For this reason, I control for the number of third parties. Second, there is possibility that the treatment of amicus has evolved over time. To account for this, I include a variable that captures a time trend.

[TABLE 5 about here]

Table 5 presents the results of this analysis in five models. Models 1 and 2 look at the effect of expressed support and institute without controls. Models 3 and 4 include the controls, and Model 5 provides a full model. An amicus receiving the expressed support of a disputing party has a strong positive and statistically significantly effect on the likelihood that an amicus is considered. Similarly, whether the amicus filer is an institute has a positive, statistically significant effect on the likelihood the content of the amicus is considered. These results are robust across models. Expressed support increases the likelihood an amicus will be considered by approximately $47 \%$, all else constant. ${ }^{14}$ If an amicus is submitted by an institute, the likelihood it is considered increases by $33 \%$, all else constant. I have speculated that institutes are more successful in having their amici considered because they probably provide more factual evidence than legal arguments. I however have not directly examined the content of their submissions to know if this is the case. ${ }^{15}$ This finding raises an important question for future research: are institutes' submissions focused on factual evidence?

\footnotetext{
${ }^{14}$ Model 5 is used to estimate the marginal effects.

15 Amicus submissions are not publicly available, with the exception of those that are made available by the amicus actors thems elves. Consequently, I do not have access to institutes' submissions to systematically analyze them.
} 
All organization types, with the exception of institutes, are not significant in any of the models, suggesting they do not explain the likelihood of amicus consideration. Also, the territorial origin of the amicus filer in the aggregate does not account for the likelihood an amicus is considered. In model 4, North American and African amicus filers have a positive, statistically significant effect on amicus consideration. These results, however, are not robust, and model 4 does not provide the best fit to the data. More importantly, there is no strong theoretical reason to think that amicus actors from these two regions will be more likely to have their submissions considered. Overall, these results suggest that the territorial origin an amicus actor does not influence whether an amicus is likely to be considered.

Finally, the controls are not significant in any of the models. This suggests that there is no underlying effect of time on the likelihood that an amicus is considered. Also, there is no statistically significant effect of the number of third parties to the dispute on the likelihood that an amicus is considered.

A qualitative analysis complements the multivariate analysis in three important ways. First, the qualitative evidence further specifies how endorsement shapes whether an amicus is considered. Second, the qualitative evidence adds robustness to the quantitative evidence concerning legal coherence. Third, the statistically analysis cannot examine the effect of whether the amicus filed to the Appellate Body are less likely to be considered because of insufficient variation. The qualitative analysis addresses the expectations with regards to the $\mathrm{AB}$ and illustrates that amicus consideration is exceedingly rare in disputes before the $\mathrm{AB}$.

\section{Accepting amici when endorsed by states}

The multivariate analysis shows that whether an amicus is considered is influence by whether a disputing party gives a generic statement supporting the consideration of the amicus 
by the panel or $\mathrm{AB}$. A qualitative assessment of this relationship reveals that a more robust form of endorsement is actually necessary for the content of amicus submission to be considered. In fact, amici are only considered when the content or arguments of amici are incorporated into the submissions of state parties. This occurs in one of two ways. First, amici have been considered by the panel if the content of the amicus submission is also presented in the written submissions or oral arguments of a party to the dispute. For example, in $E C-$ Salmon (Norway) the panel stated: "Having considered the views expressed by the parties and third parties, the Panel concluded that it would consider views expressed in the unsolicited submissions to the extent that parties decided to adopt the views expressed therein in their own submissions and arguments to the Panel."16 Similar assertions were made by the panels in several instances, suggesting that the panels accept and use an amicus submission only if a state illustrates that it agrees with the content of the submission.

Second, the panels have considered the content of an amicus brief when a state party has appended the brief to its own submissions. This has occurred with only seven amicus briefs, all of which entailed the respondent state entering the amicus into its submission as an exhibit or by making explicit reference to an amicus submission in their own submissions. The former occurred in EC-Asbestos, when the EC appended the amicus submissions of the American Federation of Labor and Congress of Industrial Organizations' brief and the brief by the Collegium Ramazzini. The panel stated that it would take these two briefs into account, "as they had been included by the EC in their own submissions on an equal footing." other four instances of an amicus briefs being appended to the respondent's brief were in $U S-$ Shrimp, Brazil - Retreaded Tyres, EC-Seal Products, and US - Tuna II.

\footnotetext{
${ }^{16}$ European Communities — Anti-Dumping Measure on Farmed Salmon from Norway WTO/DS337/R, November 17, 2006, para. 1.13.

${ }^{17}$ European Communities - Measures Affecting Asbestos and Products Containing Asbestos, Report of the Panel. WTO/DS135/R, September 18, 2000, para. 8.12).
} 
In some instances, states have said that they support aspects of the amicus or say that they think that some of the information in an amicus is likely to be of assistance to the panel. Yet, it is not sufficient for states to explain that they agree with only some aspects of an amicus. In US - Countervailing Measures on Certain EC Products, "The United States confirmed that the brief was not a part of the official submission of the United States, but that the United States agreed with much, although not all, of the brief," and the panel decided to not to take into account the brief filed by the American Iron and Steel Institute. ${ }^{18}$ In other words, a participating state must be willing to embrace and endorse all aspects of the submission for the amicus to be considered by the panel in its findings. This presents a relatively high bar for amicus submissions to be accepted and considered. In other words, the content of an amicus submission is only openly considered by the DSM when a disputing party endorses the contributions made by the amicus. The practice of only considering an amicus if it is endorsed by a disputing party enables the panels to shield itself behind the position of the endorsing state.

\section{Coherence: Procedural fairness and factual information}

A review of the panels' and AB's treatment of amicus submissions is also guided by a consistent and principled treatment of amici, reflecting their interest in maintaining a reputation with legal audiences for coherence. The multivariate analysis shows that amicus actors' territorial origin and organization type, with the exception of institutes, actors does not account for the likelihood an amicus is considered. Content analysis reveals that the WTO DSM demonstrates an interest in preserving the WTO DSM's reputation for coherence through the consistent application of two principles. First, the panels and $\mathrm{AB}$ consistently apply standards of procedural fairness in determining whether to accept an amicus. As an

\footnotetext{
${ }^{18}$ United States - Countervailing Measures Concerning Certain Products from the European Communities, Report of the Panel, WTO/DS212/R. July 31, 2002, para. 76.
} 
interviewee confirms, panels have discretion with regards to considering amicus briefs, provided they respect the due process rights of state parties. ${ }^{19}$ A principled approach based on procedural fairness has led panels to consistently reject amicus submissions that are received too late in the dispute settlement process. "Panels and the Appellate Body now tend to accept unsolicited amicus briefs, provided that they are submitted within a reasonable time frame. If they are presented once the first substantive meeting has started, they risk being disregarded" (Marceau and Hurley 2012,31).

The practice of not accepting late submissions was initiated by the panel in US-Lead and Bismuth II in 1999. The panel received a submission from the American Iron and Steel Institute in July 1999. While the panel recognized its authority to accept and consider such submissions, the panel stated: "we chose not to exercise that authority as a result of the late submission of the brief. The AISI brief was submitted after the deadline for the parties' rebuttal submissions, and after the second substantive meeting of the Panel with the parties. Thus, the parties have not, as a practical matter, had adequate opportunity to present their comments on the AISI brief to the Panel. In our view, the inability of the parties to present their comments on the AISI brief raises serious due process concerns as to the extent to which the Panel could consider the brief." ${ }^{20}$ The following year, the panel in EC-Asbestos also rejected an amicus due to the timing of its submission. Among other amicus submissions, the panel received one brief by the non-governmental organization ONE ("Only Nature Endures") in June 2000. This was several months following the second substantive meeting of the panel with the parties held in January 2000, which is when parties present their rebuttal arguments. The panel decided to not accept the brief as it "had been submitted at a stage in the procedure

\footnotetext{
${ }^{19}$ Interview A, WTO Legal Affairs Division Staff Member. Geneva, October 16, 2014.

${ }^{20}$ United States - Imposition of Countervailing Duties on Certain Hot-Rolled Lead and Bismuth Carbon Steel Products Originating in the United Kingdom WT/DS138/R. Report of the Panel, December 23, 1999, para. 6.3.
} 
when it could no longer be taken into account." ${ }^{21}$ Other amici briefs were rejected by the panels explicitly due to their tardiness. This occurred in two panels in $2006-U S-S o f t$ Lumber III and EC-Selected Customs Matters. The panels have been consistent in applying this approach. Even as recently as EC-Seal Products, an amicus was rejected on the basis of its tardiness. Table 1 shows approximately fifteen percent of amici are rejected on grounds of timing.

Applying a principled approach based on procedural fairness has also led the panels and $\mathrm{AB}$ to consistently invite the parties to a dispute to respond to amicus submissions and give them the opportunity to express their views on the submissions. As one member of the legal affairs division claimed, it is regular practice to circulate any amicus that is received to the parties and for the panel to then ask the parties for their views on whether the amicus should be taken into account as well as provide any comments they have on the content of the submission. ${ }^{22}$ These invitations extend to the third parties as well as the direct parties.

As McCall Smith (2003) has argued, an important means by which the WTO DSM has been able to ensure its reputation for coherence is through its establishment and application of procedural rules in its decision-making. Given this underlying context in which amici are viewed as a potential source of unfairness, the panels and $A B$ application of procedural fairness to amicus submission is not entirely surprising. As Mavroidis argued, in addressing amicus briefs, "due process considerations can help to ensure that there will be no undue advantage conferred to any party" $(2002,11)$. Nevertheless, this analysis empirically confirms this to be the case, and suggests that it serves the broader interests of the WTO DSM, vis-a-vis legal audiences, to demonstrate a principled and consistent approach to dealing with amici.

Second, amicus submissions are considered only in relation to the panels' factual analysis. The panels have consistently excluded from consideration any legal arguments

\footnotetext{
${ }^{21}$ European Communities - Measures Affecting Asbestos and Products Containing Asbestos WT/DS135/R. Report of the Panel, September 18, 2000, para. 8.14.

${ }^{22}$ Interview A, WTO Legal Affairs Division Staff Member. Geneva, October 16, 2014.
} 
offered by amicus briefs. For example, in the US - Tuna II, the panel received an amicus brief jointly submitted by the Humane Society International and the American University's Washington College of Law. The US "requested the Panel to review and consider the submission in its deliberations, in light of the relevant and useful information it contained which it believed could assist the Panel in understanding the issues in this dispute." ${ }^{23}$ The US cited the amicus in its opening statement as well as in its responses to the panel. The US argued consumer preferences motivated the US policy on dolphin-safe labelling of tuna. In developing this argument, the US cited the amicus brief to illustrate how consumer preferences in the US were determined by the method of fishing for tuna. ${ }^{24}$ The panel also cited the amicus submission in the reasoning of its findings. Specifically, along with other factual information, the panel referred to the amicus in determining whether the dolphin-safe labelling provisions created a technical barrier that discriminated against the import of Mexican tuna in the US. The amicus brief was used to support the conclusion that consumer sentiment and preferences contributed to the US regulations on dolphin-safe labelling and limited the marketability of non-dolphin safe Mexican tuna in the US. As the panel stated, 'the paragraphs of the amicus curiae brief to which the United States refer and the exhibits attached to the brief quoted in such paragraphs support the conclusion that such policies were prompted by the lobbying exerted by environmentalists rather than by the enactment of the DPCIA itself. ${ }^{, 25}$

Similarly, the panel in Brazil - Retreaded Tyres considered an amicus by the Humane Society International, which provided factual information concerning the effects of emissions from tire fires and the accumulation of waste tires on animal and plant life or health. The

\footnotetext{
${ }^{23}$ United States - Measures Concerning the Importation, Marketing and Sale of Tuna and Tuna Products, Report of the Panel, WTO/DS381/R, September 15, 2011. Para. VII.3.

${ }^{24}$ Ibid, para. VII.3.

${ }^{25}$ Ibid., para. VII.83.
} 
amicus was incorporated into Brazil's official submissions by attaching it as an exhibit. ${ }^{26}$ In its argumentation, Brazil referred to the factual information provided by the brief, to support its claim that the restrictions on the trade of retreaded tires were necessary to protect human and plant life and health. Similarly, an amicus submission by a group of NGOs was important to the reasoning of the panel in EC-Seal Products. ${ }^{27}$ The panel cited the amicus in its findings, when determining whether seal products derived from indigenous hunts and for resource management purposes were significantly different from commercial hunting, which were prohibited by the EU's Seals Regime and constituted most of Canadian and Norwegian seal hunts. Among other things, the amici were cited by the panel in determining whether commercial hunts were unlike indigenous or resource management hunts in terms of animal welfare and humane killings. ${ }^{28}$ Drawing on amici for the purpose of making factual determinations, as opposed to legal determinations, is a principle that the WTO panels has consistently applied.

\section{Appellate Body and Amicus Submissions}

The panels and the $\mathrm{AB}$ respond quite differently to amicus submissions. The multivariate analysis illustrated that an amicus brief submitted to the $\mathrm{AB}$ is less likely to be considered than those submitted to the panel. In only one instance has the $\mathrm{AB}$ stated that an amicus merits some consideration. Specifically, in EC-Sardines the AB found that the amicus submitted by the government of Morocco presented an original legal argument. ${ }^{29}$ Ultimately, the $\mathrm{AB}$ found that this submission was not necessary to consider, but this was the closest the $\mathrm{AB}$ has come to taking an amicus into account. This in itself was a unique case

\footnotetext{
${ }^{26}$ Brazil - Measures Affecting Imports of Retreaded Tyres, Report of the Panel. WTO/DS332/R June 12, 2007.

${ }^{27}$ Interview C, Amicus filer, Geneva, October 18, 2014.

${ }^{28}$ European Communities - Measures Prohibiting the Importation and Marketing of Seal Products, Report of the Panel. WTO/DS400/R; WTO/DS401/R. November 25, 2013.

${ }^{29}$ European Communities - Trade Description of Sardines, Report of the Appellate Body. WTO/DS231/AB/R, September 26, 2002.
} 
because the amicus was a member state of the WTO. In all other instances, the AB has refrained from officially taking into account the arguments presented to it by amici.

The fact that the $\mathrm{AB}$ does not consider amicus briefs is a consequence of its political and legal constraints being greater compared to the panels. First, the $\mathrm{AB}$ is in a more precarious position vis-à-vis states, and the $\mathrm{AB}$ most likely treats amicus submissions in light of its past experience of backlash by states. ${ }^{30}$ The AB's treatment of amicus submission in $E C$ - Asbestos generated intense dissatisfaction on the part of several member states, manifesting in special session of the General Council as well as influencing the appointment of the members of the AB (Elsig and Pollack 2014, 405). Second, the AB's treatment of amicus submissions is also the result of legal constraints the panels do not face. Specifically, the $A B$ does not make rulings on the factual claims of a dispute. Article 17(6) of the DSU restricts the AB's legal authority to only questions of law, not fact. To consider amicus submissions for the purpose of factual analysis would be an obvious infringement of this provision. Moreover, drawing on an amicus for the legal analysis could potentially harm the AB's reputation with legal communities because it would suggest that the $\mathrm{AB}$ did not have sufficient capacity itself to interpret the law or that it was unduly influenced by non-legal authorities. Overall, the combination of political and legal constraints makes the threshold for consideration higher for an amicus submission to the $\mathrm{AB}$ than to the panels. As a result, the $\mathrm{AB}$ has to a very minimal extent accepted amicus curiae submissions.

\section{Conclusion}

\footnotetext{
${ }^{30}$ One interviewee confirmed that the $\mathrm{AB}$ most likely did keep past experience in mind when it receives an amicus. Interview B, WTO Legal Affairs Division Staff Member. Geneva, October 18, 2014.
} 
This article has aimed to map amicus participation in the WTO DSM, and to explain when the panels and $\mathrm{AB}$ are likely to take an amicus curiae brief into consideration. The analysis has two main findings. First, the mapping of amicus submissions shows that the WTO DSM amicus briefs are filed in a relatively small portion of disputes - both for the panels and for the $\mathrm{AB}$. Amicus actors are also diverse, coming from most world regions and are filed by all types of organizations - albeit to varying degrees. Moreover, when they are filed, there are rarely accepted and considered. In other words, access is highly conditional.

Second, this article shows that acceptance and consideration of an amicus curiae brief depends on the satisfaction of two conditions, one shaped by political constraints and the other by legal constraints. First, the amicus must be endorsed by a state party to the dispute. States endorse amicus briefs either by appending them or duplicating the information presented by the amicus. Second, the acceptance and consideration of an amicus must accord with the WTO DSM's reputation for coherence. Demonstrating the WTO DSM will treat amicus similarly and according to the same principles is important to ensuring that legal audiences view it as a legitimate legal authority. The WTO DSM has applied two principles consistently to its treatment of amicus curiae submissions: their consideration must not undermine fairness to the disputing parties, and they can be used for factual, but not legal, analysis. In addition, the article finds that the combination of political and legal constraints also makes it very unlikely that amicus briefs will be taken into consideration by the Appellate Body.

These findings advance our understanding of amicus in the WTO beyond what previous literature suggested. First, the data reveals that contrary to some early speculations there is more diversity among the amici filers than previously thought. Amicus submissions come from actors of various regions of the world and from different types of organizations. This is not simply about the access and participation of NGOs and environmental 
organizations from the global North. Second, it confirms previous findings that the panels and $\mathrm{AB}$ address amicus briefs that are supported by a party to the dispute (Dunoff 2006, 660).

Although I have found that there is more nuance to how states express support for or endorse an amicus, the pattern has largely persisted. ${ }^{31}$ The fact that this pattern holds not only confirms that the WTO DSM is politically constrained, but that political backlash has some sustaining power to constrain in the long-run. In other words, the institutional memory for the early response of states to amicus briefs is long.

Third, early research on amicus submissions posited that principles of procedural fairness would apply to how the WTO DSM entertains the briefs (for example, Mavroidis 2002). This article shows empirically that procedural fairness does indeed play a role in how amicus are processed. This is an important finding because it illustrates that not all aspects of how the WTO DSM responds to amicus can be understood through political constraints. Instead, we see that coherence, which is commonly understood as a cornerstone to the rule of law and legitimate legal authority does guide the treatment of amicus submissions. Moreover, the commitment to coherence, as seen through the application of a principle of procedural fairness, occurs prior to the question of whether or not a party endorses the amicus. In other words, concerns for the WTO DSM's reputation for coherence appears to affect the decision of whether to accept an amicus, while endorsement relates more to the question of the content is taken into consideration.

These finding provide both good and bad news for non-state actor involvement. For those who view amicus access as a detriment to the WTO dispute settlement system, this analysis is good news. It suggests that there is generally a high threshold to be met before an amicus is accepted and considered by the WTO DSM. It also reveals that the most

\footnotetext{
${ }^{31}$ Dunoff stated that consideration only occurred when an amicus was appended to a party's submissions. I find that appending an amicus is only way in which endorsement occurs. Endorsement also occurs when a party duplicates information in their own submissions. This distinction is important because the latter is a way of selecting in only certain parts on an amicus, while the former is an endorsement of the amicus in its entirety.
} 
controversial aspect of the DSM's work, legal interpretation is largely unaffected by non-state actor involvement. To date, amicus curiae submissions have only been expressly considered on the basis of the factual information provided.

For those who view amicus submissions as a much needed means of participation in the WTO, this analysis is perhaps bad news. The article has shown that acceptance and consideration of an amicus is quite exceptional and conditional on satisfying both the political and legal constraints faced by the panels and $\mathrm{AB}$. The relatively high threshold for access, in terms of actually being included in how a legal dispute is adjudicated, means that the formal ability to access the panels and the $\mathrm{AB}$ rarely translates into participation. Thus, for the proponent of non-state actors' involvement, amicus access holds limited promise for participation.

The article has implications beyond the WTO DSM. Increasingly scholars have studied the opening up of global governance to non-state actors, both across the WTO's different organs and in other international organizations (Tallberg et al. 2013, O'Brien et al. 2000, Hanegraaff et al. 2015, Steffek, Kissling, and Nanz 2008). This article adds to this literature, suggesting that even though access may be formally granted to non-state actors, in practice it may be conditional. For example, this article has shown that not all actors who take advantage of access privileges receive access in the end. Moreover, these findings suggest that the conditionality of access might contribute to whether access translates into non-state actors' participation and influence. As this paper has shown, the conditionality of access for amici can be viewed as good news for those who are concerned that it allows for the undue influence of special interests but also bad news for those who view it as a promise for greater participation in global governance. 


\section{Bibliography}

Alter, Karen J. 2008. "Agents or Trustees? International Courts in their Political Context." European Journal of International Relations 14(1): 33-63.

Busch, Marc L., and Krzysztof J. Pelc. 2010. "The Politics of Judicial Economy at the World Trade Organization." International Organization 64(2): 257-279.

Busch, Marc L., and Eric Reinhardt. 2006. "Three's A Crowd: Third Parties and WTO Dispute Settlement." World Politics 58(3): 446-477.

Carrubba, Clifford J., Matthew Gabel, and Charles Hankla. 2008. "Judicial Behavior under Political Constraints: Evidence from the European Court of Justice." American Political Science Review 102(4): 435-452.

Charnovitz, Steve. 2000. "Opening the WTO to Nongovernmental Interests." Fordham International Law Journal 24: 173-216.

Dunoff, Jeffrey L. 1998. "The misguided debate over NGO participation at the WTO." Journal of International Economic Law 1(3): 433-456.

Dunoff, Jeffrey L. 2006. "Constitutional Conceits: The WTO's 'Constitution' and the Discipline of International Law." European Journal of International Law 17(3): 647675.

Dworkin, Ronald. 1986. Law's empire. Cambridge, Mass: Belknap Press.

Elsig, Manfred, and Mark Pollack. 2014. "Agents, trustees, and international courts: The politics of judicial appointment at the World Trade Organization." European Journal of International Relations 20(2): 391-415.

Esty, Daniel C. 1998. "Non-governmental organizations at the World Trade Organization: cooperation, competition, or exclusion." Journal of International Economic Law 1(1): 123-148.

Franck, Thomas M. 1990. The power of legitimacy among nations. Oxford: Oxford University Press.

Franck, Thomas M. 1995. Fairness in international law and institutions. Oxford: Clarendon Press.

Garrett, Geoffrey, R. Daniel Kelemen, and Heiner Schulz. 1998. "The European Court of Justice, National Governments, and Legal Integration in the European Union." International Organization 52(1): 149-176.

Ginsburg, Tom. 2013. "Political Constraints on International Courts." In The Oxford Handbook of International Adjudication, edited by Cesare Romano, Karen Alter and Yuval Shany, 483-502. Oxford: Oxford University Press.

Hanegraaff, M., J. Beyers, and C. Braun. 2011. "Open the door to more of the same? The development of interest group representation at the WTO." World Trade Rev. 10(4): 447-472.

Hanegraaff, Marcel, Caelesta Braun, Dirk De Bièvre, and Jan Beyers. 2015. "The Domestic and Global Origins of Transnational Advocacy: Explaining Lobbying Presence During WTO Ministerial Conferences." Comparative Political Studies 48(12): 1591-1621.

Kelemen, Daniel. 2001. "The Limits of Judicial Power: Trade-Environment Disputes in the GATT/WTO and the EU." Comparative Political Studies 34(6): 622-650.

Larsson, Olof, and Daniel Naurin. 2016. "Judicial Independence and Political Uncertainty: How the Risk of Override Affects the Court of Justice of the EU." International Organization 70(2): 377-408.

Marceau, Gabrielle, and Mikella Hurley. 2012. "Transparency and Public Participation: A Report Card on WTO Transparency Mechanisms." Trade, Law and Development 4(1): 19-44. 
Mavroidis, Petros C. 2002. "Amicus Curiae Briefs Before the WTO: Much Ado About Nothing." Jean Monnet Working Paper 2/01.

McCall Smith, James. 2003. "WTO dispute settlement: the politics of procedure in Appellate Body rulings." World Trade Review 2(1): 65-100.

O'Brien, Robert, Anne Marie Goetz, Jan Aart Scholte, and Marc Williams. 2000. Contesting Global Governance: Multinational Economic Institutions and Global Social Movements. Cambridge: Cambridge University Press.

Scholte, Ja, R. O'Brien, and M. Williams. 1999. "The WTO and civil society." J. World Trade 33(1): 107-123.

Shaffer, Gregory C. 2001. "The world trade organization under challenge: Democracy and the law and politics of the WTO's treatment of trade and environment matters." Harvard Environmental Law Review 25(1): 1-93.

Slotboom, Marco M. 2006. "Participation of NGOs before the WTO and EC tribunals: which court is the better friend?" World Trade Review 5(01): 69-101.

Squatrito, Theresa. 2012. "Opening the Doors to the WTO Dispute Settlement: State Preferences on NGO Access as Amici." Swiss Political Science Review 18(2): 175198.

Steffek, Jens, Claudia Kissling, and Patrizia Nanz. 2008. Civil Society Participation in European and Global Governance: A Cure for the Democratic Governance. New York: Palgrave Macmillan.

Steinberg, Richard H. 2004. "Judicial Lawmaking at the WTO: Discursive, Constitutional, and Political Constraints." American Journal of International Law 98(2): 247-275.

Stone Sweet, Alec, and Thomas L. Brunell. 2013. "Trustee Courts and the Judicialization of International Regimes. The Politics of Majoritarian Activism in the European Convention on Human Rights, the European Union, and the World Trade Organization." Journal of Law and Courts 1(1): 61-88.

Tallberg, Jonas, Thomas Sommerer, Theresa Squatrito, and Christer Jönsson. 2013. The Opening Up of International Organization: Transnational Access in Global Governance. Cambridge: Cambridge University Press

Trachtman, Joel P., and Philip M. Moremen. 2003. "Costs and benefits of private participation in WTO dispute settlement: whose right is it anyway?" Harvard International Law Journal 44(1): 221-250.

Umbricht, Georg C. 2001. "An 'Amicus Curiae Brief' on Amicus Curiae Briefs at the WTO." Journal of International Economic Law: 773-794.

Van den Bossche, Peter 2008. "NGO Involvement in the WTO: A Comparative Perspective." Journal of International Economic Law. 


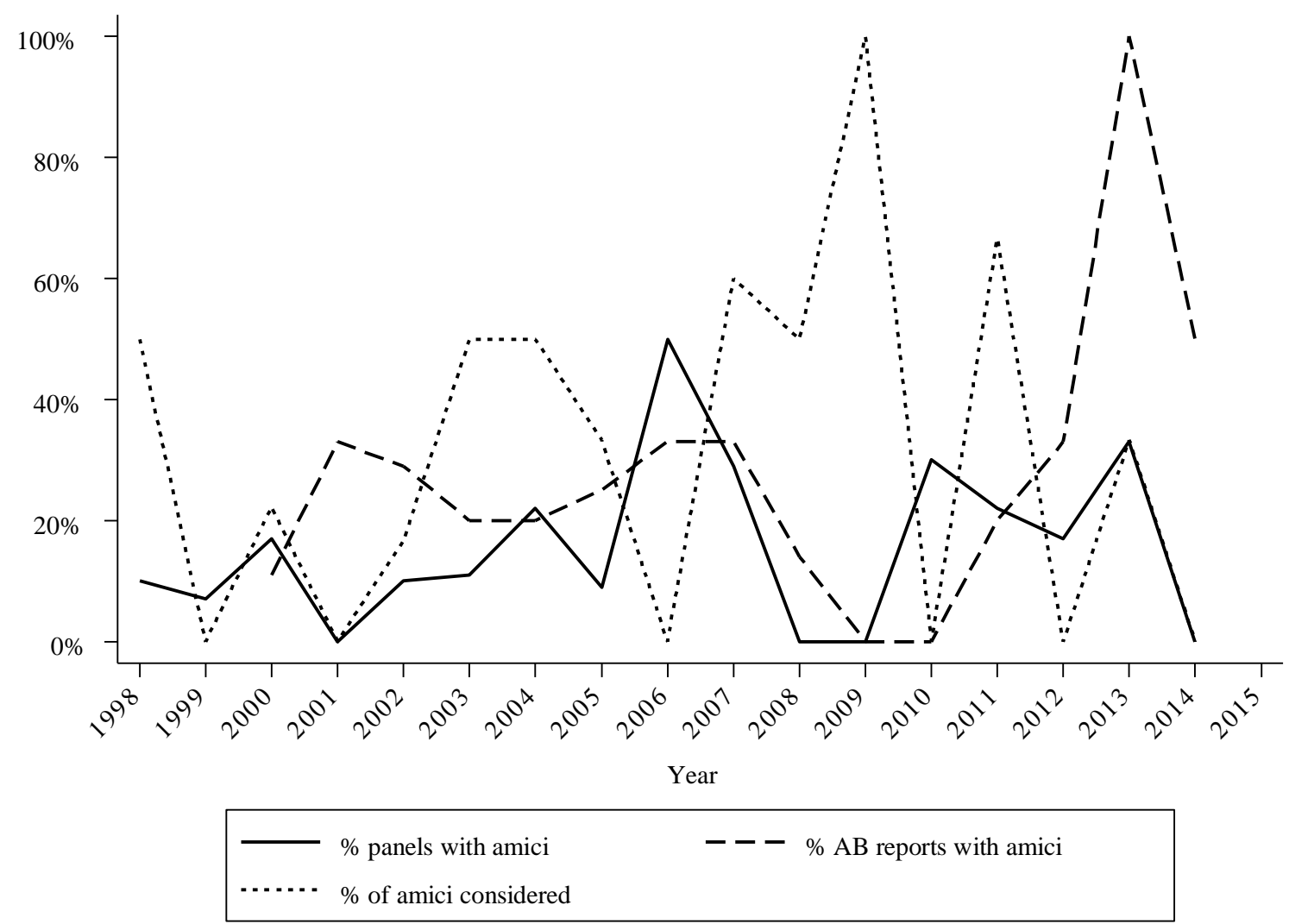

Figure 1. Annual proportion of panel and Appellate Body reports with amici and yearly rates of amicus consideration 
Table 1. Territorial origin of actors who filed amici $(N=148)$

\begin{tabular}{|c|c|}
\hline Territorial origin & Percentage of all amici actors \\
\hline Africa & $2.70 \%$ \\
Asia & 6.76 \\
Europe & 30.41 \\
N. America & 37.84 \\
Oceania & 2.03 \\
S. America & 10.81 \\
Unknown & 9.46 \\
\hline
\end{tabular}


Table 2. Organization type of actors who filed amici $(N=148)$

\begin{tabular}{|c|c|}
\hline Organization type & Percentage of all amici actors \\
\hline Business & $21.62 \%$ \\
Labor & 5.41 \\
NGO & 44.59 \\
Institute & 12.16 \\
Individual & 8.78 \\
unknown & 7.43 \\
\hline
\end{tabular}


Table 3. Panel and Appellate Body Responses to Amicus Submissions

\begin{tabular}{|c|c|c|}
\hline Type of Response & & Percent of Amicus \\
\hline Not considered & & $81.5 \%$ \\
\hline \multirow[t]{4}{*}{ Reason: } & - Reason is not expressed by panel or $\mathrm{AB}$ & $30.4 \%$ \\
\hline & $\begin{array}{l}\text { - Rejected on grounds that the panel/AB } \\
\text { deems it unnecessary to consider }\end{array}$ & 33.7 \\
\hline & - Rejected on grounds of timing & 15.2 \\
\hline & - Other & 2.2 \\
\hline Considered & & 18.5 \\
\hline
\end{tabular}

$\mathrm{N}=92$. An addition six amicus submission were coded as having an unknown response by the panel or $\mathrm{AB}$. 
Table 4. Rate Amici are Considered by Territorial Origin and Organization Type

\begin{tabular}{|lll|llc|}
\hline $\begin{array}{l}\text { Territorial origin of } \\
\text { amici }\end{array}$ & $\begin{array}{l}\text { Percent } \\
\text { considered }\end{array}$ & $N$ & $\begin{array}{l}\text { Organization type of } \\
\text { amici }\end{array}$ & $\begin{array}{l}\text { Percent } \\
\text { considered }\end{array}$ & $N$ \\
\hline Africa & $25.00 \%$ & 4 & Business & $2.86 \%$ & 35 \\
Asia & 0.00 & 10 & Labor & 25.00 & 4 \\
Europe & 17.65 & 17 & NGO & 25.00 & 16 \\
N. America & 21.21 & 33 & Institute & 33.33 & 6 \\
Oceania & 0.00 & 2 & Individual & 20.00 & 10 \\
S. America & 0.00 & 6 & unknown & 36.36 & 11 \\
unknown & 28.57 & 14 & more than one type & 20.00 & 10 \\
more than one region & 33.33 & 6 & & & \\
\hline
\end{tabular}


Table 5. Binomial Logistic Regression of Amicus Consideration

\begin{tabular}{|c|c|c|c|c|c|}
\hline & Model 1 & Model 2 & Model 3 & Model 4 & Model 5 \\
\hline Expressed support & $\begin{array}{l}2.391 * \\
(1.09)\end{array}$ & & $\begin{array}{l}4.236^{*} \\
(1.88)\end{array}$ & & $\begin{array}{l}3.954^{*} \\
(1.85)\end{array}$ \\
\hline Institute & & $\begin{array}{l}1.872 * * \\
(0.69)\end{array}$ & & $\begin{array}{l}3.046^{* *} \\
(1.17)\end{array}$ & $\begin{array}{l}2.898^{*} \\
(1.24)\end{array}$ \\
\hline Europe & & & $\begin{array}{l}1.386 \\
(1.06)\end{array}$ & $\begin{array}{l}1.085 \\
(0.86)\end{array}$ & $\begin{array}{l}1.257 \\
(0.96)\end{array}$ \\
\hline$N$ America & & & $\begin{array}{l}1.185 \\
(0.72)\end{array}$ & $\begin{array}{l}1.886^{* * *} \\
(0.68)\end{array}$ & $\begin{array}{l}1.412 \\
(0.73)\end{array}$ \\
\hline Africa & & & $\begin{array}{l}2.863 \\
(1.50)\end{array}$ & $\begin{array}{l}2.163^{*} \\
(0.91)\end{array}$ & $\begin{array}{l}2.115 \\
(1.19)\end{array}$ \\
\hline S America & & & $\begin{array}{l}0.525 \\
(1.26)\end{array}$ & $\begin{array}{l}0.159 \\
(1.20)\end{array}$ & $\begin{array}{l}0.909 \\
(1.41)\end{array}$ \\
\hline$N G O$ & & & $\begin{array}{l}2.673 \\
(1.74)\end{array}$ & $\begin{array}{l}1.381 \\
(0.82)\end{array}$ & $\begin{array}{l}3.024 \\
(2.00)\end{array}$ \\
\hline Labor & & & $\begin{array}{l}1.603 \\
(1.28)\end{array}$ & $\begin{array}{l}1.552 \\
(1.22)\end{array}$ & $\begin{array}{l}2.101 \\
(1.59)\end{array}$ \\
\hline Individual & & & $\begin{array}{l}3.571 \\
(2.03)\end{array}$ & $\begin{array}{l}1.870 \\
(1.39)\end{array}$ & $\begin{array}{l}3.921 \\
(2.22)\end{array}$ \\
\hline Third parties & & & $\begin{array}{l}0.040 \\
(0.06)\end{array}$ & $\begin{array}{l}0.046 \\
(0.06)\end{array}$ & $\begin{array}{l}0.021 \\
(0.08)\end{array}$ \\
\hline Time trend & & & $\begin{array}{l}-0.071 \\
(0.07)\end{array}$ & $\begin{array}{l}-0.029 \\
(0.06)\end{array}$ & $\begin{array}{l}-0.034 \\
(0.08)\end{array}$ \\
\hline Constant & $\begin{array}{l}-2.140 * * \\
(0.76)\end{array}$ & $\begin{array}{l}-1.872 * * * \\
(0.53)\end{array}$ & $\begin{array}{l}-5.529 * * \\
(2.12)\end{array}$ & $\begin{array}{l}-4.459 * * * \\
(1.36)\end{array}$ & $\begin{array}{l}-6.084 * \\
(2.45)\end{array}$ \\
\hline$N$ & 92 & 81 & 78 & 78 & 78 \\
\hline AIC & 0.838 & 0.879 & 0.841 & 1.004 & 0.831 \\
\hline Log likelihood & -36.539 & -33.609 & -21.799 & -28.152 & -20.410 \\
\hline
\end{tabular}

Note: Standard errors are clustered by dispute (in parentheses).

$* \mathrm{p}<0.05, * * \mathrm{p}<0.01, * * * \mathrm{p}<0.001$ 
Appendix: Disputes in which at least one amicus curiae submission

\begin{tabular}{|c|c|c|c|}
\hline Case Name (short title) & Dis pute Number & Date of report & $\begin{array}{l}\text { Number } \\
\text { of amici }\end{array}$ \\
\hline \multicolumn{4}{|l|}{ Panel } \\
\hline$\overline{U S-S h r i m p}$ & 58 & 15 May 1998 & 2 \\
\hline US - Lead and Bismuth II & 138 & 23 December 1999 & 1 \\
\hline EC-Asbestos & 135 & 18 September 2000 & 5 \\
\hline$E C-$ Bed Linen & 141 & 30 October 2000 & 1 \\
\hline US-Section 110(5) Copyright Act & 160 & 15 June 2000 & 1 \\
\hline US - Softwood Lumber III & 236 & 27 September 2002 & 4 \\
\hline US - Softwood Lumber IV & 257 & 29 August 2003 & 3 \\
\hline US - Softwood Lumber VI & 277 & $22 \operatorname{March} 2004$ & 1 \\
\hline EC - Export Subsidies on Sugar & $265,266,283$ & 15 October 2004 & 1 \\
\hline$U S-$ Zeroing $(E C)$ & 294 & 31 October 2005 & \\
\hline EC-Selected Customs Matters & 315 & 16 June 2006 & 1 \\
\hline EC-Biotech Products & 291, 292, 293 & 29 September 2006 & 3 \\
\hline Brazil-Retreaded Tyres & 332 & 12 June 2007 & 2 \\
\hline EC-Salmon (Norway) & 337 & 16 November 2007 & 3 \\
\hline EC-Large Civil Aircraft & 316 & 30 June 2010 & 1 \\
\hline Australia - Apples & 367 & 9 August 2010 & 1 \\
\hline Thailand-Cigarettes (Philippines) & 371 & 15 November 2010 & 1 \\
\hline US - Tuna II (Mexico) & 381 & 15 September 2011 & 1 \\
\hline$U S-C O O L$ & 384,386 & 18 November 2011 & 1 \\
\hline Canada-Renewable Energy & 412,426 & 19 December 2012 & 2 \\
\hline EC-Seal Products & 400,401 & 25 November 2013 & 5 \\
\hline \multicolumn{4}{|l|}{ Appellate Body } \\
\hline US - Lead and Bismuth II & 138 & 10 May 2000 & 2 \\
\hline Thailand-H-Beams & 122 & 12 March 2001 & 1 \\
\hline EC-Asbestos & 135 & $12 \operatorname{March} 2001$ & 31 \\
\hline$E C-$ Sardines & 231 & 26 September 2002 & 2 \\
\hline $\begin{array}{c}\text { US-Countervailing Measures on } \\
\text { Certain EC Products }\end{array}$ & 212 & 9 December 2002 & 1 \\
\hline US - Steel Safeguards & $\begin{array}{l}248,249,251,252 \\
253,254,258,259\end{array}$ & 10 November 2003 & 1 \\
\hline US - Softwood Lumber IV & 257 & 19 January 2004 & 2 \\
\hline EC-Export Subsidies on Sugar & $265,266,283$ & 28 April 2005 & 1 \\
\hline EC-Chicken Cuts & 269,286 & 12 September 2005 & 1 \\
\hline Mexico - Taxes on Soft Drinks & 308 & 6 March 2006 & 1 \\
\hline Brazil-Retreaded Tyres & 332 & 3 December 2007 & 2 \\
\hline China - Auto Parts & $339,340,342$ & 15 December 2008 & 1 \\
\hline $\begin{array}{l}\text { US - Anti-Dumping and } \\
\text { Countervailing Duties (China) }\end{array}$ & 379 & 11 March 2011 & 1 \\
\hline US-Clove Cigarettes & 406 & 4 April 2012 & 2 \\
\hline US - Tuna II (Mexico) & 381 & 16 May 2012 & 3 \\
\hline Canada-Renewable Energy & 412,426 & 6 May 2013 & 2 \\
\hline EC-Seal Products & 400,401 & 22 May 2014 & 3 \\
\hline
\end{tabular}

